\title{
Entrepreneurial passion, orientation and behavior: the moderating role of linear and nonlinear thinking styles
}

\author{
Lamberto Zollo and Riccardo Rialti \\ School of Economics and Management, University of Florence, Florence, Italy \\ Alberto Tron \\ Department of Finance, Bocconi University, Milan, Italy, and \\ Cristiano Ciappei \\ School of Economics and Management, University of Florence, Florence, Italy
}

\begin{abstract}
Purpose - The purpose of this paper is to unpack the underlying mechanisms of entrepreneurs' passion, orientation and behavior by investigating the role of rational and nonrational cognitive elements. Building on dual process theory and sociointuitionism, a conceptual model is proposed in order to explore the relationship between entrepreneurial passion, entrepreneurial orientation (EO) and strategic entrepreneurship behavior (SEB). Specifically, entrepreneurs' linear thinking styles (System 2) and nonlinear thinking styles (System 1) are hypothesized as being significant moderators of such a relationship.

Design/methodology/approach - Covariance-based structural equation modeling (CB-SEM) is used to empirically validate the proposed conceptual model and test the moderating hypotheses on a sample of 300 entrepreneurs actively involved in European small and medium enterprises (SMEs).

Findings - Entrepreneurial passion is shown to be a significant antecedent of EO, which, in turn, strongly influences SEB. Moreover, entrepreneurs' linear thinking style positively moderates the EO-SEB relationship, but not the link between passion and EO. Instead, a nonlinear thinking style positively moderates the relationship between passion and EO, but not the links between EO and SEB.

Practical implications - Entrepreneurs should trust their nonlinear thinking style - related to affective/ emotive and intuitive information processing systems - to foster the effect of their entrepreneurial passion on EO. Furthermore, entrepreneurs should rely on a linear thinking style, namely the rational and deliberative cognitive processes, to enhance the impact of their EO on SEB.

Originality/value - Dual process theory and sociointuitionism are integrated to simultaneously investigate the effect of nonrational and rational cognitive mechanisms on entrepreneurs' orientation and behavior. Moreover, the proposed model is empirically tested on a sample of entrepreneurs working in SMEs located in Europe, which have received little attention from entrepreneurship scholars in comparison to their US counterparts. The authors' findings suggest important implications for entrepreneurs, policymakers and entrepreneurial universities educators.
\end{abstract}

Keywords Entrepreneurial passion, Entrepreneurial orientation, Strategic entrepreneurship behavior, Intuition, Emotion, SMEs

Paper type Research paper

(C) Lamberto Zollo, Riccardo Rialti, Alberto Tron and Cristiano Ciappei. Published by Emerald Publishing Limited. This article is published under the Creative Commons Attribution (CC BY 4.0) licence. Anyone may reproduce, distribute, translate and create derivative works of this article (for both commercial and non-commercial purposes), subject to full attribution to the original publication and authors. The full terms of this licence may be seen at http://creativecommons.org/licences/by/4.0/legalcode

Ethical approval: All procedures performed in studies involving human participants were in accordance with the ethical standards of the institutional and/or national research committee and with the 1964 Helsinki declaration and its later amendments or comparable ethical standards.

Informed consent. Informed consent was obtained from all individual participants included in the study.

Received 28 October 2019 Revised 25 February 2020 6 April 2020

Accepted 6 April 2020

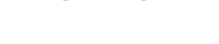


$\mathrm{MD}$

59,5

974

\section{Introduction}

Small businesses with less than 50 employees make up the vast majority of enterprises in the 28 [1] EU countries. Accordingly, they represent more than the $98 \%$ of enterprises in most European economic industries. Similar figures can also be seen in EFTA (European Free Trade Associations) countries, such as Switzerland, where they account for $95 \%$ of enterprises, and in extra EU countries such as the United States, which has more than $30 \mathrm{~m}$ small enterprises (representing 99.5\% of the total business industry). Medium enterprises - comprised of between 50 and 249 employees - represent between the $0.5 \%$ and the $2 \%$ of the number of organizations in developed countries (Caputo et al., 2018). These enterprises impact national economies as they usually account for around $60 \%$ of total employment and, furthermore, contribute to around $35-50 \%$ of the total value added. As a result, small and medium enterprises (SMEs) are extremely important to the economic growth of countries worldwide (Adomako et al., 2016). In light of this importance, academic research has traditionally placed a lot of emphasis on these types of businesses (Biraglia and Kadile, 2017). In particular, scholars have focused on which factors allow SMEs to innovatively defend their competitive advantage in highly competitive markets (Dabić et al., 2019). Apart from organizational factors, such as ambidexterity, agility and the ability to adapt to changing environments (Rialti et al., 2019), a general consensus exists regarding the crucial role of the entrepreneurs in charge of most of these businesses (Pellegrini et al., 2020). Entrepreneurs, indeed, are characterized by their high capacity when it comes to stress resistance, risk tolerance and persuasiveness by virtue of their creativity and long-range orientation (Gartner, 1990; Davidsson et al., 2006; Laudano et al., 2019). They are scrupulous owners, eager to invest their own economic resources in order to succeed in value generation. As such, entrepreneurs frequently represent the strategic differential between successful and prospering businesses and unprofitable ones, which seem to resist change (Lechter, 2001; Futterer et al., 2018).

Notwithstanding the importance of entrepreneurs when it comes to SME success, the current economic environment poses an increasingly growing number of threats. The simple assumption that "good" entrepreneurs are directly related to the success of a business is insufficient. In contemporary organizations, as a result of the dynamic and unstable changes affecting highly competitive markets (Pellegrini et al., 2016), one of the most challenging aspects for entrepreneurs is how to improve the development of successful entrepreneurial activities, creating socioeconomic value for the community in general. Specifically, scholars have analyzed the antecedents of strategic entrepreneurship behavior (SEB) - namely the ability to exploit and innovatively generate opportunities - to identify the main levers through which to improve the creation, success, longevity and survival of entrepreneurial firms (Kantur, 2016). According to various authors, entrepreneurial orientation (EO) represents one of the main antecedents of SEB, encompassing an entrepreneur's degree of innovativeness, their proactiveness and their propensity to take risks (Anderson et al., 2015; Covin and Slevin, 1988; Lumpkin and Dess, 1996). As a result, decision-makers showing enhanced EO are more capable of acting strategically and effectively identifying opportunities and threats (Zollo et al., 2017a).

Despite this, the scholarly literature on entrepreneurial decision-making - and the consequent literature on SEB - is still fragmented (Ireland and Webb, 2009) and, at least, is limited in the following points. Firstly, few scholars have assessed the elements affecting the relationship between EO and SEB, especially with regard to the possible antecedents and predictors of such a link. In this context, entrepreneurial passion (EP) could be considered fundamental support when it comes to the success of entrepreneurial activities as this positive feeling enhances the persistence and motivation that are often associated with the role and identity of being an entrepreneur (Cardon et al., 2009, 2013). As such, it seems relevant to investigate the role of $\mathrm{EP}$ as a possible significant predictor of the relationship between $\mathrm{EO}$ and SEB. Secondly, while pertinent academic literature has mainly focused on the positive 
outcomes of EO, such as the aforementioned SEB (Anderson et al., 2015), less is known about the underlying micromechanisms that might influence links between entrepreneurial attitudes and behavior, at either a rational or a nonrational level. Such a limitation could be addressed through reliance on modern cognition science (Haidt, 2001; Kahneman, 2003; Stanovich and West, 2000), which increasingly stresses the key role of both conscious and unconscious information processing systems. While entrepreneurship scholars have traditionally focused on linear thinking styles, related to rational, deliberative and fully conscious cognitive processes, such a rationalist and positivist perspective is extremely reductive (Zhong, 2011; Zollo et al., 2017b). Though entrepreneurs need to think rationally in everyday strategymaking decisions, nonlinear elements, such as emotive, intuitive and unconscious information processing systems, also significantly impact upon the effectiveness of entrepreneurs' strategic decision-making behavior (Vance et al., 2007; Groves et al., 2008, 2011; Orlandi and Pierce, 2019). This is particularly true nowadays, when cognitive rational mechanisms often fail to satisfy an entrepreneur's need to successfully exploit new market opportunities (Pellegrini et al., 2016; Zollo, 2020). To fill these gaps, this research aims to answer the following research question: how do entrepreneurs' linear and nonlinear thinking styles affect the relationship between entrepreneurial passion, orientation and strategic behavior?

To these ends, we build on dual process theory (Kahneman, 2003) and sociointuitionism (Haidt, 2001) in order to propose and empirically test a conceptual model that unpacks the existing micromechanisms describing entrepreneurial decision-making and behavior formation. Specifically, entrepreneurs' linear and nonlinear thinking styles are hypothesized as being moderators of these links. The model is tested on a sample of 300 entrepreneurs actively involved in European SMEs. Covariance-based structural equation modeling (CB-SEM) is used to validate the model and test the hypothesized relationships. As a result, a linear thinking style emerges as a positive mediator of EO-strategic behavior links, but not of the EP. Instead, a nonlinear thinking style can be seen to enhance the relationship between EP and EO, but not the relationship between EO and SEB. This relevant interplay between rational (or linear) and nonrational (or nonlinear) thinking styles in entrepreneurship formation is relevant to both theory and practice.

In the next section, the theoretical background is introduced through the reviewing of historical and recent studies on EP, EO and SEB. The hypothesized relationships between these variables, the moderating effects of linear and nonlinear thinking styles and our conceptual model are also presented. The third section of the paper provides the research methodology used to empirically test the proposed framework. In the fourth section, the analysis and results are illustrated. Finally, the fifth section of the paper discusses the theoretical and practical implications resulting from the empirical evidence, and in the last section, limitations of the paper and suggestions for future research are presented.

\section{Theoretical background and hypotheses development 2.1 Entrepreneurial passion}

Seminal research on entrepreneurship has assessed the relationship between entrepreneurship and economic growth (Wright and Stigliani, 2013). Accordingly, entrepreneurship has been identified as (1) a factor nurturing the economical sustainability of lesser developed countries; (2) an element influencing regional GDPs' growth through the creation of new jobs (Fayolle, 2007); (3) a response to unemployment (Baptista and Thurik, 2007); (4) a key driver of innovation (Audretsch, 2012); and (5) a means of female empowerment (Laudano et al., 2019; Ramadani et al., 2015). Entrepreneurship is therefore a social phenomenon characterized by a social function. Scholarly attention has increasingly turned toward the "person" behind entrepreneurship-related phenomena, namely the entrepreneur (Zollo et al., 2016). According to Knight (1921), an entrepreneur is someone that
Linear and nonlinear thinking styles 
is willing to tolerate economic risk in order to commercialize something new to the market and thus obtain a profit. Moving on from these assumptions, research has been refined over the years in order to include the multifaceted traits of entrepreneurs while observing the drivers influencing their success or lack of success. For example, successful entrepreneurs commonly share several personality characteristics, such as a willingness to make business-related risks, openness toward new ideas and innovation, consciousness with regard to duties and tasks and high levels of empathy (Greenwood and Suddaby, 2006). Among the personal elements linked to entrepreneurial success, a pivotal role has been recently attributed to EP. According to Cardon et al. (2009, p. 517), passion is "consciously accessible, intense positive feelings experienced by engagement in entrepreneurial activities associated with roles that are meaningful and salient to the self-identity of the entrepreneur." EP is then a powerful and positive feeling deriving from strong identification with specific entrepreneurial activities (Cardon et al., 2013). Thus, passion within the entrepreneurial realm encompasses two main dimensions: affect and self-identity. With regard to the first, affect includes positive feelings, such as joy, zeal, deep longing and the willingness to succeed in an entrepreneurial venture (Cardon and Kirk, 2015). Passion, therefore, derives from intense cause-related emotions that encourage entrepreneurs to think and act. Instead, the self-identifying concept is related to entrepreneurs' inner identification with entrepreneurial activities and their cognitive understanding of the personal meaning of being an entrepreneur (Bao et al., 2017). Such a subjective perception of oneself as an entrepreneur - in spite of a white-collar worker or a manager - arises as a key factor arousing passion (Vignoles et al., 2006). As a result, it is possible to observe the ways in which passion might significantly influence an entrepreneur's active involvement in their job. This intense feeling is capable of generating motivational energy in entrepreneurs, stirring their tenacity, initiative and determination amidst difficulties (Cardon et al., 2017). From this perspective, Breugst et al. (2012) and Cardon et al. (2013) have identified that passion (1) influences entrepreneurs to improve what they are doing during their daily routines; (2) keeps them focused on the success of their ventures, even when they are not working; and (3) makes them feel positive about the future.

EP manifests itself through three main domains, which correspond to three different identities that entrepreneurs can assume from the inception of their venture (Cardon and Kirk, 2015). According to Gartner et al. (1999), depending on the diverse life stages of a venture, entrepreneurs self-recognize themselves differently. During the early phases of a venture, entrepreneurs commonly identify themselves as "founders" and, as such, passion for founding is the first typology of passion that entrepreneurs usually experience (Vignoles et al., 2006). Passion, in such a case, is the feeling that influences the intention to establish a new venture, including the willingness to complete all of the documentation required for its incorporation and the willingness to seek funding from external sources (Cardon et al., 2013). Passion then stands behind the decision to take risks and face the uncertainty and stress associated with a new venture. Recently, scholars have observed that subjects with previously successful entrepreneurial experiences tend to show higher levels of passion when it comes to founding (Newman et al., 2019). The second identity that entrepreneurs usually assume is the "inventor," which corresponds to the second typology of passion: the one for inventing. This kind of passion manifests during the initial growth of the venture, when entrepreneurs need to innovate and identify new possibilities for success. The feeling that entrepreneurs experience in this moment is related to the excitement deriving from the recognition of new opportunities emerging in the market and the joy deriving from the accessible ability to exploit them (Cardon and Kirk, 2015). Contextual factors, such as creative surroundings, might nurture a passion for inventing. These environments could indeed potentially provide individuals with new ideas when it comes areas that could be exploited. The final identity of the entrepreneur is the "developer," which pertains to the passion that an entrepreneur might have when it comes to investing time and resources into growing his/her 
business (Cardon et al., 2009). Indeed, passion is a feeling that may help entrepreneurs to develop and grow their business. Among the dynamics triggering this last type of passion, Newman et al., (2019) have highlighted the fundamental importance of previous business and management expertise. Thus, EP could be considered to be a harmonious and intense positive feeling, deeply influencing the founding and subsequent growth of a business by generating stimuli through which to identify and propose new opportunities (Milanesi, 2018).

In terms of outcomes, recent research on entrepreneurship and emotions, such as passion, shows that entrepreneurs characterized by higher than average levels of passion have larger networks (Davis et al., 2017) and are more capable when it comes to gathering and motivating their employees (Breugst et al., 2012; Newman et al., 2019). In addition to this, optimism and the persistent desire (i.e. "persistence") to succeed at one's own ventures have been shown to be common outcomes (Milanesi, 2018). Passion is, in fact, a driver of entrepreneurial willingness when it comes to acquiring the new competencies needed to run a venture's dayto-day operations (Biraglia and Kadile, 2017). As a result, passion can impact entrepreneurial capability with regard to reacting to change, entrepreneurial creativity and willingness to take risks.

\subsection{The role of passion in entrepreneurial orientation and behavior}

Consistently, pertinent scholarly literature has investigated the ways in which passion might foster EO (Wang, 2008). EO is the ability to identify new entrepreneurial opportunities and then turn them into new growth trajectories (Cardon et al., 2013; Montiel Campos, 2017). This construct has been thoroughly explored at an organizational level, that is, how processes, practices and internal decision-making activities allow for the exploitation of creativity by virtue of an increased awareness, allowing entrepreneurs to generate new opportunities (Lumpkin and Dess, 1996; Kantur, 2016). However, EO also exists at an individual level, constituting the individual's ability to adapt to new situations and reap the emerging benefits while not underscoring risks. The relationship between $\mathrm{EO}$ and entrepreneurial behavior has traditionally been explored through social cognitive theory (SCT; Bandura, 2012), which explains how personal traits and emotions can influence behavior, as well as inputs from the environment. Individual $\mathrm{EO}$ derives from a set of emotions, beliefs and willingness to succeed and is typically associated with EP. In particular, alertness deriving from passion may foster entrepreneurs' proactiveness and their ability to detect new possibilities emerging in the market (Cardon et al., 2013). Therefore, passion could affect individual EO through enhanced "entrepreneurial alertness," which is their capacity to identify treats to the venture (Montiel Campos, 2017), and entrepreneurs' dynamism, which is the speed at which an entrepreneur can develop new solutions to new problems or exploit new situations (Adomako et al., 2016). Gerschewski et al. (2016) stressed that EP is related to entrepreneurs' perseverance, which could influence their willingness to succeed, which is typical of individuals displaying EO. Building on this, we propose:

\section{H1. EP positively influences EO.}

In turn, literature has widely observed the relationship between EO and SEB, which is a set of behaviors implemented by strategy-prone entrepreneurs through their firms (Anderson et al., 2019). Usually, strategic behaviors of entrepreneurs consist of the intensive pursuit of innovation through research of and reactiveness to change and rapidly evolving environments, by taking greater risks than their nonstrategical counterparts. Strategic entrepreneurs are then more capable of identifying emerging opportunities and reaping any benefits from their environment, even in complex situations. Similarly, entrepreneurs are more capable of capitalizing on their own innovations (Biraglia and Kadile, 2017). According to Kollmann et al. (2007). According to Kollmann et al. (2007), EO could influence SEB, as 
individuals with high levels of $\mathrm{EO}$ are more autonomous, proactive, competitive, aggressive and thus have the propensity to identify and exploit new opportunities.

Therefore, we propose the following hypothesis:

H2. EO positively influences SEB.

\subsection{Entrepreneurs' linear and nonlinear thinking styles}

The academic literature on entrepreneurial behavior, orientation and decision-making has traditionally relied on a rationalist-positivist perspective, which stresses the role of entrepreneurs' rationality when making a decision or choice or behaving in a certain way (Sonenshein, 2007; Zhong, 2011). In this way, the current conceptualization of entrepreneurial decision-making is almost fully rational, consequential, deliberative and utilitarian in nature (Pellegrini et al., 2016; Zollo et al., 2017b). This emphasis on logical, empirical and analytical cognitive processes has led scholars to refer to entrepreneurs' thinking style as "linear" decision-making (Vance et al., 2007, p. 233; see also Groves et al., 2011). However, scholars are increasingly recognizing the uncertain, unpredictable, unexpected and highly dynamic nature of the contexts in which entrepreneurs usually make decisions and choices (Groves et al., 2008; Orlandi and Pierce, 2019; Pellegrini et al., 2016). In such contexts, managers' and entrepreneurs' nonlinear "thinking patters as intuition, emotional assessments, creativity, holistic evaluation, imagination and visualization, and insight" assume a key role (Vance et al., 2007, p. 233; see also Sadler-Smith and Shefy, 2004). In fact, according to Vance et al. (2007, p. 168), the linear thinking style, composed of reason, logic and rationality, "is less useful for understanding complex and unpredictable nonlinear systems."

As a consequence, scholars agree that modern socioeconomic circumstances require entrepreneurs and managers to rely heavily on their emotions and intuitions, also known as "gut feelings" and "hunches" (Zollo, 2020, p. 2). Pertinent scholarly literature defines intuition as "thoughts and preferences that come to mind quickly and without much reflection" (Kahneman, 2003, p. 697). Hence, decision-makers' nonlinear thinking emerges quickly, effortlessly and automatically. Moreover, intuition has been defined as a cognitive conclusion, resulting from decision-makers' "previous experiences and emotional inputs" (Burke and Miller, 1999, p. 92), thus stressing the affective/emotive component of nonlinear thinking (Zollo et al., 2018). On the contrary, linear thinking is mainly characterized by slow, thoughtful and deliberative cognitive information processing (Haidt, 2001). Furthermore, linear thinking is typically used by decision-makers to rationally re-evaluate and justify their decisions and behavior (Sonenshein, 2007; Woiceshyn, 2011). This "dual" process model of decision-making (Kahneman, 2003; Stanovich and West, 2000) has thus acquired more and more acknowledgment in literature on entrepreneurial cognition (Dane and Pratt, 2007; Zhong, 2011). On the one hand, decision-makers' rational and deliberative cognitive processes play an important role in making decisions, influencing behavior and being intentional, controllable and consciously accessible. At the same time, decision-makers' emotive and intuitive cognitive processes represent a key counterpart in these information processing systems, being fast, effortless, automatic and unconscious (Dane and Pratt, 2007; Sonenshein, 2007). This perspective - "two minds in one brain" (Evans, 2008, p. 268) - is consistent with what cognition scientists call the "systems framework" (Haidt, 2001; Kahneman, 2003; Stanovich and West, 2000). System 2 refers to the linear, rational and deliberative information processing system of decision-makers, while System 1 refers to the nonlinear, emotive and intuitive cognitive system of decision-makers (for a review see Zollo et al., 2017b). Specifically, System 1 might be interpreted as "An experiential and unconscious system of innate, rapid, parallel, automatic, instinctive behaviors, and information processing," and System 2 as "The slow, controlled, logical, and sequential general purpose reasoning system of conscious, abstract, hypothetical, and algorithmic thinking" (Zollo, 2020, p. 6). 
Consistent with the aforementioned, one of the most widely acknowledged psychological theories stressing the importance of intuition and emotion in decision-making is Haidt's (2001) sociointuitionism. Haidt stressed the a priori role of emotive and intuitive cognitive processes, resulting in a judgment, which will be post hoc deliberated by rational cognitive processes. Although these mechanisms of cognition are simultaneous and work in parallel (Kahneman, 2003; Stanovich and West, 2000), the sociointuitionist model emphasizes the importance of nonrational and unconscious information processing systems, namely emotive and intuitive processes leading to "affect-laden intuitions" (Haidt, 2001). Thus, the "emotional unconscious" represents one of the main drivers of a decision-maker's information processing system (Zollo, 2020). Furthermore, the sociointuitionist framework also suggests that a decision-maker's judgments, resulting from emotive and intuitive insights, will significantly impact upon other decision-makers' choices and behaviors (Haidt, 2001). Building on this, Zollo (2020) recently theorized that emotions and intuition - decisionmakers' System 1 - are key drivers of interpersonal persuasion and social influence in ethical decision-making. Such a psychological perspective has been increasingly used by business scholars interested in better investigating the role of emotion and intuition in decision-makers, managers and entrepreneurs (Dedeke, 2015; Schwartz, 2016; Woiceshyn, 2011). Through this, the role of the nonlinear thinking style of entrepreneurs and managers has been increasingly emphasized by recent scholars (Orlandi and Pierce, 2019; Zollo et al., 2018).

Building on this, we attempt to unpack entrepreneurs' decision-making by hypothesizing that it is not only the linear thinking style (System 2) that is a significant underlying mechanism of entrepreneurs' cognition, but also that the nonlinear thinking style (System 1) might represent an important cognitive counterpart able to explain how EP, EO and behavior work together. Specifically, we hypothesize that the conditional effect of passion on EO and, in turn, conditional effect of EO on SEB differ depending on different levels of an entrepreneur's linear and nonlinear thinking style. In fact, the aforementioned definition of $\mathrm{EP}$ (Cardon et al., 2009) significantly stresses the role of feelings and experience in motivating entrepreneurs' decision-making, orientation and behavior. Hence, it seems reasonable to hypothesize that key elements of nonlinear thinking - such as emotions and intuition - have a significant effect on the relationships between EP, EO and consequent strategic behavior. According to Dane and Pratt (2007), intuition is composed of two subelements: intuiting and emotional processing. "Intuiting allows decision makers to unconsciously and holistically elaborate external stimuli to make rapid and intuitive judgments when facing dynamic, uncertain, and fast-changing situations requiring immediate cognitive holistic associations" (Zollo, 2020, p. 6), and emotional processing expresses the experiential state of decisionmakers by channeling intuition toward conscious reasoning. As a result, the passion, EO and SEB of entrepreneurs are all likely to be highly impacted by nonlinear thinking during unpredictable and unstable socioeconomic situations (Pellegrini et al., 2016). Because System 2 represents the simultaneous and parallel cognitive counterpart to System 1 (Haidt, 2001), it is also plausible to hypothesize a significant moderating influence of entrepreneurs' key elements of linear thinking, such as logical, analytical, hypothetical and rational deliberation, on their passion, their orientation and ultimately their behavior. Specifically, linear thinking allows entrepreneurs to intentionally and consciously deliberate critical situations by making rational decisions (Zollo, 2020). As a result, an interplay (Woiceshyn, 2011; Zollo et al., 2017b) between linear and nonlinear cognitive mechanisms influences the underlying links between entrepreneurs' passion, orientation and resulting behavior.

Hence, the following hypotheses are proposed:

H3a. Entrepreneurs' linear thinking style significantly moderates the relationship between $\mathrm{EP}$ and $\mathrm{EO}$.
Linear and nonlinear thinking styles 
$\mathrm{MD}$

59,5

980
H3b. Entrepreneurs' linear thinking style significantly moderates the relationship between EO and SEB.

H4a. Entrepreneurs' nonlinear thinking style significantly moderates the relationship between $\mathrm{EP}$ and $\mathrm{EO}$.

$H 4 b$. Entrepreneurs' nonlinear thinking style significantly moderates the relationship between $\mathrm{EO}$ and SEB.

\subsection{Hypothesized model}

In order to answer to our research questions - which concern the impact of linear and nonlinear entrepreneurial thinking styles on the relationships between EP, EO and SEB - we have developed the conceptual model illustrated in Figure 1.

As shown in Figure 1, EP is hypothesized to be a predictor of EO, which, in turn, is considered to be an antecedent of SEB. Specifically, entrepreneurs' linear (System 2) and nonlinear (System 1) thinking styles are proposed to be moderators of these relationships. In this way, we attempt to unpack the cognitive underlying mechanisms of entrepreneurs' decision-making, orientation and behavior.

\section{Research methodology}

\subsection{Sampling}

The Prolific data collection online platform (Rialti et al., 2019) was used to distribute an electronic link to our survey, which was directed to entrepreneurs actively involved in European SMEs. The respondents returned 300 completed and useable questionnaires, a response rate of $36.8 \%$, in line with previous studies' entrepreneur response rates. $156(52 \%)$ were men and $144(48 \%)$ were women. Most were 30-40 years old (56.2\%), and most were from the most "entrepreneurial countries" of Europe [3], such as the United Kingdom (19.5\%), the Netherlands (18.8\%), Scandinavia $(14.2 \%)$ and Germany $(12.6 \%)$. The sample demographics are reported in Table 1.

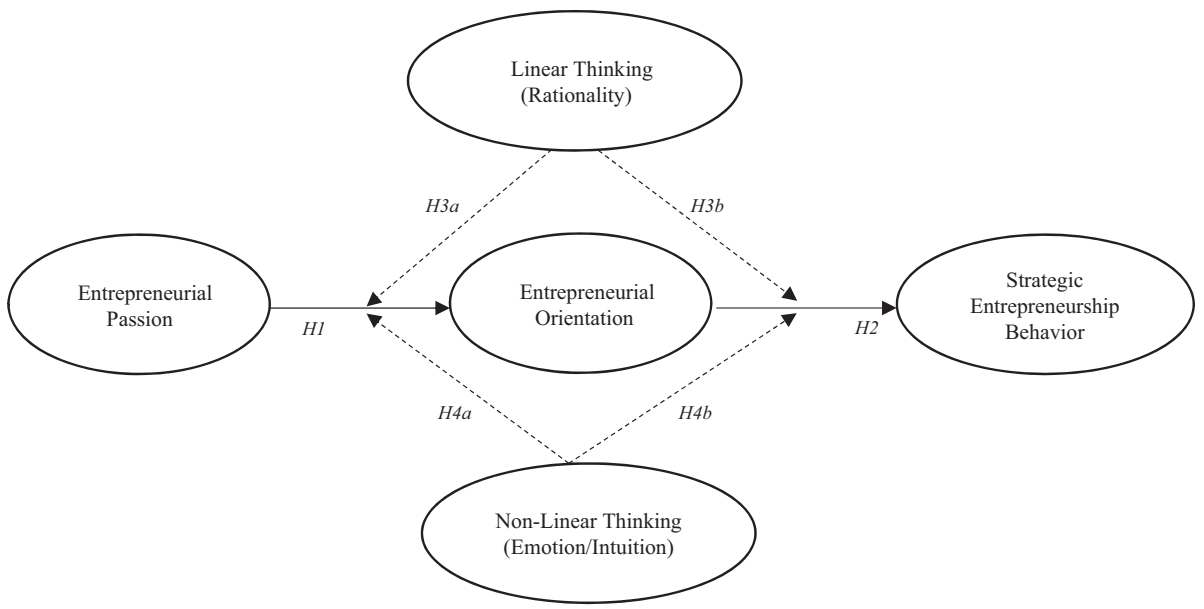

Note(s): Dotted lines indicate the hypothesized moderating effects in the conceptual model
Figure 1.

Conceptual model 


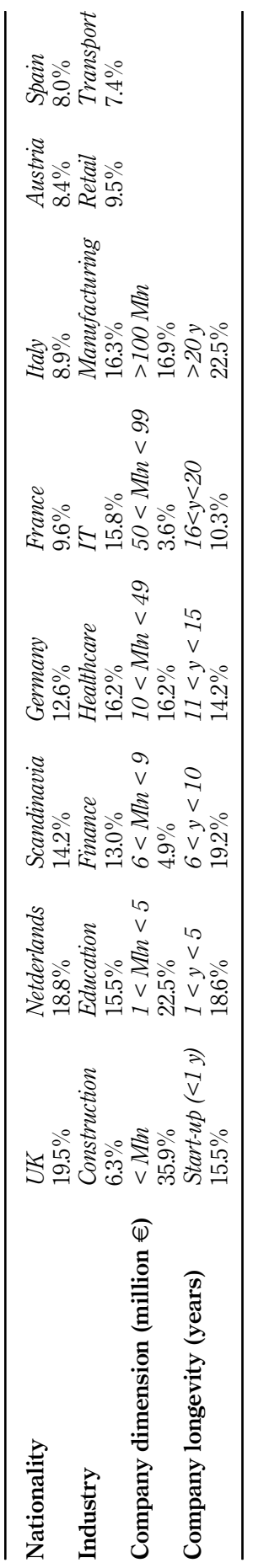

Linear and nonlinear thinking styles

981

Table 1. 
$\mathrm{MD}$

59,5

982

\subsection{Measures}

We developed a structured questionnaire composed of 40 items (observed variables) related to our five main latent variables, namely EP, EO, SEB and linear and nonlinear thinking styles. All of the items sought to capture "individual-level" entrepreneurial characteristics (either cognitive or attitudinal/behavioral) and were previously validated by pertinent academic literature. Seven-point Likert scales were used, ranging from completely disagree (1) to completely agree (7). In addition to this, we also used control variables, such as gender, age, country of origin, firm size and so on, in an attempt to alleviate potential demophysiographic differences in our respondents.

EP was measured using the 13-item scale used by Cardon et al. (2013) (e.g. "It is exciting to figure out new ways to solve unmet market needs that can be commercialized").

EO was captured using the original subdimensions of Lumpkin and Dess, (1996): innovativeness, proactiveness and risk-taking propensity (see also Covin and Slevin, 1988). Specifically, we used the recently adapted scale of Laskovaia et al. (2019): EO-innovativeness was thus a three-item scale (e.g. "In general, I favor a strong emphasis on R\&D, technological leadership, and innovations in my firm"); as was EO-proactiveness (e.g. "In dealing with my competitors, I am very often one of the first to introduce new products/services, administrative techniques, operating technologies, etc. in my business"); and EO-risktaking (e.g. "When confronted with decision-making situations involving uncertainty, I typically adopt a bold, aggressive posture in order to maximize the probability of exploiting potential opportunities of my firm").

We measured SEB using the methods used by Kantur (2016): this nine-item scale directly assesses the actual entrepreneurial behavior of the respondents (e.g. "I adopted new strategies to exploit new opportunities in my firm" or "I adopted flexible organizational structures to foster innovation in my firm").

Finally, to measure entrepreneurs' linear and nonlinear thinking styles, we used the tenitem method developed by Vance et al. (2008), which aims to assess the importance given by respondents to cognitive elements such as intuition/emotion (System 1) and rationality/logic (System 2) in decision-making. Linear thinking style was measures on a five-item scale (e.g. "I primarily weigh quantitative factors when making a decision about a large purchase or investment, such as my age, budget needs, or future earnings"); as was nonlinear thinking style (e.g. "I primarily rely on my feelings when making career decisions").

\section{Analysis and results}

4.1 Means, scale reliabilities and correlation analysis

In Table 2 we present the scales' means, standard deviation and reliabilities values, as well as the correlation analysis results.

Table 2.

Correlation matrix, validity and reliability of the constructs

\begin{tabular}{lccccccccr}
\hline Variable & M & SD & CR & AVE & 1 & 2 & 3 & 4 & 5 \\
\hline 1. Ent passion & 4.88 & 1.26 & 0.865 & 0.700 & $(0.93)$ & & & & \\
2. Ent orientation & 3.90 & 1.46 & 0.798 & 0.680 & $0.399^{*}$ & $(0.89)$ & & & \\
3. SEB & 3.96 & 1.59 & 0.720 & 0.625 & $0.474^{*}$ & $0.615^{*}$ & $(0.91)$ & & \\
4. Linear thinking & 5.34 & 1.13 & 0.677 & 0.510 & $0.330^{*}$ & $0.176^{*}$ & $0.235^{*}$ & $(0.70)$ & \\
5. Nonlinear thinking & 4.51 & 1.35 & 0.688 & 0.515 & $0.222^{*}$ & $0.152^{*}$ & 0.092 & $-0.203^{*}$ & $(0.83)$
\end{tabular}

Note(s): $* p<0.01$

Cronbach's alpha values on the diagonal. CR: composite reliability; AVE: average variance extracted $M=$ Mean; SD: standard deviation; Ent passion: entrepreneurial passion; Ent orientation: entrepreneurial orientation; SEB: strategic entrepreneurial behavior 
As Table 1 shows, linear thinking style had the highest mean $(M=5.34$; $\mathrm{SD}=1.13)$, followed by non-EP $(M=4.88$; $\mathrm{SD}=1.26)$ and nonlinear thinking $(M=4.51$; $\mathrm{SD}=1.35)$. All variables were acceptable in terms of reliability, showing Cronbach alpha's values ranging between 0.70 (linear thinking) and 0.93 (EP). Hence, all variables were retained in the following analyses. As expected, in the correlation analysis, linear and nonlinear thinking styles were negatively correlated $(r=-0.203 ; p<0.01)$. The highest Pearson's $r$ values were between $\mathrm{EO}$ and SEB $(r=+0.615 ; p<0.01)$ and $\mathrm{EP}$ and SEB $(r=+0.474$; $p<0.01$ ), thus confirming the positive linear correlation between our entrepreneurshiprelated variables. Interestingly, there was no significant correlation between SEB and nonlinear thinking $(\phi>0.10)$, which, instead, was significantly correlated with EP $(r=+0.222 ; p<0.01)$.

\subsection{Measurement model and confirmatory factor analysis}

For the first step of the CB-SEM analysis, we assessed the validity and psychometric properties of our hypothesized model by conducting a confirmatory factor analysis (CFA) with the AMOS software (v.25; Arbuckle, 2011). The maximum likelihood function of AMOS was used to estimate parameters, such as the factor loadings and covariances of the proposed five-construct (EP, EO, SEB and linear and nonlinear thinking styles) model. Firstly, we built a measurement model and examined the goodness-of-fit measures to verify the acceptable parsimony of the analyzed model (Bagozzi and $\mathrm{Yi}, 1988$ ). In terms of absolute fit indexes, the relative Chi-square suggests a good fit with a $T$-test of $\chi^{2} / \mathrm{df}=2.55$ (lower than 3 , as required). In addition, the goodness-of-fit index (GFI) (0.951) suggests a good fit. Finally, the root mean square error of approximation (RMSEA) of 0.046 suggests an acceptable model fit of less than 0.07 , as required. In terms of the relative fit indexes, the most commonly used were the comparative fit index (CFI), the incremental fit index (IFI), the normed fit index (NFI) and the Tucker-Lewis index (TLI), also known as the nonnormed fit index. As a result, the model indicates acceptable fit indexes $(\mathrm{CFI}=0.972 ; \mathrm{IFI}=0.958 ; \mathrm{NFI}=0.950 ; \mathrm{TLI}=0.961)$, all above 0.90 .

The measurement model showed that all factor loadings - the path coefficients between the indicators and the latent variable - were significant $(\phi<0.01)$. To assess the internal consistency of the indicators, we estimated the composite reliability (CR) for each latent construct. CR values higher than 0.6 are required (Bagozzi and $\mathrm{Yi}, 1988$ ). As shown in Table 2 , all of our variables showed acceptable $\mathrm{CR}$ values ranging from 0.677 (linear thinking style) to 0.865 (EP). Convergent validity was assessed through the average of variance extracted (AVE), which estimates the indicators' amount of variance accounting for the latent construct (Fornell and Larcker, 1981). AVE values higher than 0.5 indicate good convergent validity (Bagozzi and Yi, 1988). All constructs show acceptable values of AVE, higher than 0.7, as reported in Table 2. Moreover, to assess the models' discriminant validity, the square root of the constructs' AVEs had to be greater than the correlations between the model constructs (Fornell and Larcker, 1981). The square roots of all constructs' AVEs are greater than the correlations reported in Table 1, thus indicating acceptable discriminant validity. The overall fit indexes of the model and the reliability and validity analysis suggest an acceptable model fit (Jamali et al., 2019; Zollo et al., 2019).

Finally, we considered the presence of common method bias (CMB) following the procedures suggested by Podsakoff et al. (2003). Firstly, we pretested the scales to delete unclear items from the questionnaire. Secondly, we conducted Harman's one-factor test, which failed to identify a general factor that accounted for the majority of the total variance, although this was equal to $28.65 \%$. Next, we conducted a CFA to compare our proposed model with a model loading all items onto a common method factor: the "one-factor model" (Podsakoff et al., 2003). The comparison yielded a significant change in Chi-square. As
Linear and nonlinear thinking styles 
$\mathrm{MD}$

59,5

required, the $\chi 2$ difference test with one degree of freedom was greater than 3.84 , which is the critical value associated with $p=0.05$. Our proposed model showed a superior fit to the data with regard to the "one-factor model" (Podsakoff et al., 2003), thus suggesting that CMB was unlikely to be a significant threat (Faraoni et al., 2019; Nosi et al., 2020; Rialti et al., 2020; Zollo et al., 2017c).

\section{4}

\subsection{Hypotheses testing}

In the second step of the CB-SEM analysis, AMOS (v.25; Arbuckle, 2011) was used to estimate a structural model through which to assess the hypothesized path coefficients between the constructs. Firstly, we assessed the absolute and relative fitting indexes of our proposed structural model (Figure 1). For the absolute fit indexes, the relative Chi-square $(\chi 2 / \mathrm{df})=2.42$ was below the cutoff value of 3.0, as required. The GFI (0.962) was higher than 0.90, as required. The RMSEA of 0.040 was satisfactory as a value below 0.07 is expected for an acceptable fit. In addition to this, the relative fit indexes were above 0.90 (CFI $=0.979$; $\mathrm{NFI}=0.974$; $\mathrm{IFI}=0.960$; TLI $=0.968$ ), suggesting an adequate model fit (Bagozzi and Yi, 1988). We could therefore proceed with our estimation of the hypothesized relationships and the moderation analysis.

Figure 2 reports the results of the estimated coefficients of the structural equation model analysis.

Firstly, we assessed the relationships between EP, EO and SEB (H1 and H2). As shown in Figure 2, EP had a significant and positive effect $(\beta=+0.38, p<0.01)$ on $\mathrm{EO}$, thus providing statistical support for H1. Similarly, EO had a strong and positive effect $(\beta=+0.75, p<0.01)$ on SEB, thus confirming H2. The explanatory power of the model was high, as illustrated by the multiple squared correlation value $\left(R^{2}\right)$, which was equal to $68 \%$. This means that the model was able to account for two-thirds of the variance of the dependent variable.

Next, we proceed with the moderation analysis (Hayes, 2017). To empirically test the moderating effect of linear and nonlinear thinking styles, we created several "interaction variables" using SPSS (v.25; Field, 2013). The moderation analysis required us to compute the

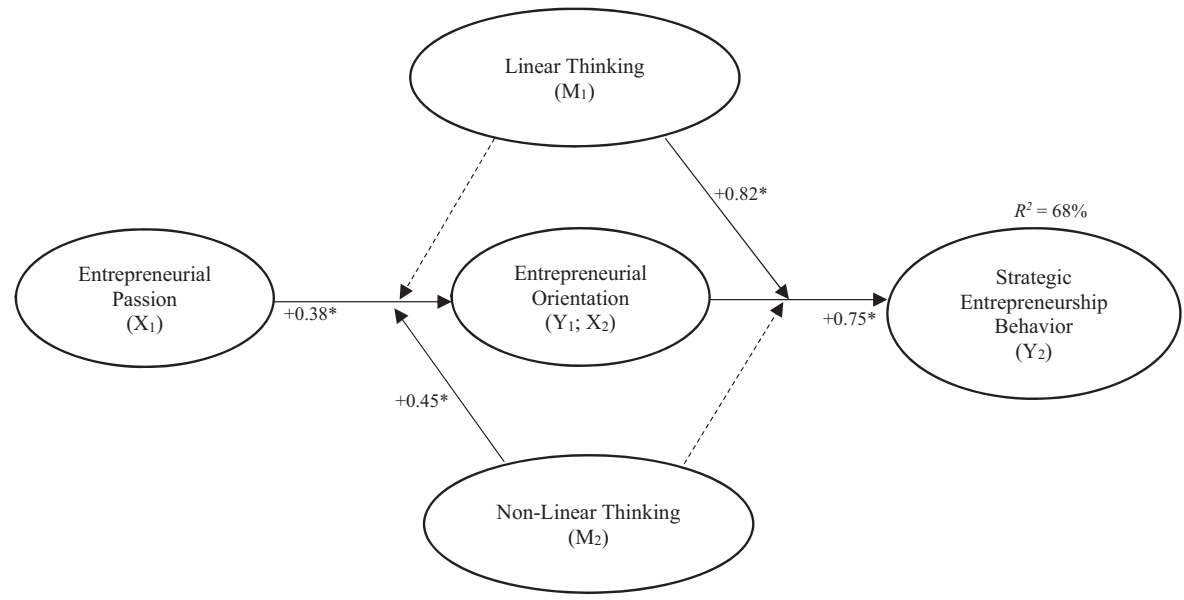

Figure 2.

Results of the moderation analysis
Note(s): $* p<0.01$

Dotted lines indicate non-significant paths. Standardized beta coefficients are reported $R^{2}$ : this indicates the multiple square correlation referring to the \% of variance explained of the dependent variable $\mathrm{X}$ : independent variable; Y: dependent variable; M: moderating variable 
interaction/joint effect of the antecedent/predictor (variable $X$ ) and the moderating variable (variable $M$ ) on the dependent/outcome variable (variable $Y$ ) (Hayes, 2017; Field, 2013) [2]. We computed two interaction variables by combining EP $\left(X_{1}\right)$ with linear thinking style $\left(M_{1}\right)$ (ENT_PASSxLINEAR) and EP $\left(X_{1}\right)$ with nonlinear thinking style $\left(M_{2}\right)$ (ENT_PASSxNON_LINEAR). In this way, it was possible to calculate the hypothesized conditional effect of $\mathrm{EP}$ on $\mathrm{EO}\left(Y_{1}\right)$, moderated by linear thinking style and nonlinear thinking style, respectively. Next, we computed two interaction variables by combining $\mathrm{EO}\left(\mathrm{X}_{2}\right)$ with linear thinking style $\left(M_{1}\right)$ (EOxLINEAR) and EO $\left(X_{2}\right)$ with nonlinear thinking style $\left(M_{2}\right)$ (EOxNON_LINEAR). In this way, we could assess the hypothesized conditional effect of EO on SEB $\left(\overline{Y_{2}}\right)$ moderated by linear and nonlinear thinking style, respectively.

As a result of the moderation analysis, linear thinking style $\left(M_{1}\right)$ had no significant moderating effect $(p>0.10)$ on the relationship between EP and EO, thus not confirming H3a; instead, linear thinking style $\left(M_{2}\right)$ positively moderated the relationship between EO and $\mathrm{SEB}$, which increased at $\beta=+0.82(\phi<0.01)$. Hence, H3b was confirmed. For nonlinear thinking style $\left(M_{2}\right)$, we observed an oppositional situation: this variable positively moderated the relationship between EP and EO, which increased at $\beta=+0.45(\phi<0.01)$, but had no significant moderating effect $(\phi>0.10)$ on the EO/SEB relationship. Thus, H4a was confirmed, but not H4b. Overall, the results indicated a significantly higher impact of EP on EO for high levels of nonlinear thinking style (but not linear thinking) and a significant higher impact of EO on SEB for high levels of linear thinking style (but not nonlinear). In other words, entrepreneurs' System 1 cognitive processes positively moderated the relationship between EP and EO, but had no significant effect on the EO/SEB relationship, while entrepreneurs' System 2 positively moderated the relationship between EO and SEB, showing no significant effect on the relationship between EP and EO.

\section{Discussion and implications}

\subsection{Theoretical implications}

This research contributes to entrepreneurship literature in several ways. Our empirical results expand the stream of literature concerning positive emotions - such as EP - and entrepreneurship. In fact, while extant literature has already explored the existing relationship between $\mathrm{EO}$ and $\mathrm{SEB}$, scholars have largely neglected the possible antecedents of such a link (Ferreira et al., 2015). Our findings show that EP is a relevant predictor of EO and, in turn, of SEB. It is then possible to conclude that the passion an entrepreneur shows toward their job and their enterprise might significantly influence the formation of $\mathrm{EO}$ and the consequent formation of SEB. In line with recent findings (Montiel Campos, 2017), entrepreneurs characterized by high levels of passion are more autonomous, innovative and proactive and are characterized by higher risk-taking propensities. Passion is truly a motivational construct that characterizes highly committed entrepreneurs in their business life with high locus of control, thus attributing meaning to their working life. These individuals will thus do their best to make their business succeed, even amidst difficulties. Consequently, passionate entrepreneurs are more prone to behave strategically and are more prone to scan the environment for new opportunities in which to invest their time and resources and pursue potential profits.

Secondly, our findings allow us to extend the field of literature on entrepreneurial thinking styles (Abatecola et al., 2018). Indeed, while theoretically investigations have been conducted questioning whether or not an interplay between rational and nonrational thinking styles exists, this has been scantly tested in an empirical setting (Pellegrini and Ciappei, 2015; Laudano et al., 2019; Zollo et al., 2017b). With this in mind, our research extends the existing knowledge on micromechanisms driving EO and behavior both in a "conscious" and in an "unconscious" way. Building on the dual process theory (Kahneman, 2003; Stanovich and
Linear and nonlinear thinking styles

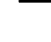


West, 2000) and the sociointuitionist model (Haidt, 2001), our empirical findings show that a nonlinear/intuitive/emotive thinking style (or System 1) is fundamental to the transformation of EP into EO. Linear/rational thinking (or System 2) is shown to be what instigates the transformation of EO into SEB. Thus, the results show that entrepreneurs think nonrationally when passion matters more than strategy and they start to think rationally when focused on emerging opportunities and when figuring out how to exploit these in order to overcome competitors.

Findings from this research show how the process that facilitates the transition from EP to SEB is mediated by EO. Particularly, our evidences highlight the significant role of both linear and nonlinear styles in entrepreneurial decision-making and behavior formation (Pellegrini and Ciappei, 2015). Entrepreneurs, then, unconsciously change their thinking style in different phases of their decision-making. As stressed before, these results could shed some light on the understanding of which enterprises may succeed and which may experience more entrepreneur-related difficulties during their life cycle.

\subsection{Practical implications}

With regard to managerial and practical contributions, our results have significant implications for entrepreneurs and policymakers. Specifically, because of the emergence of entrepreneurship education among entrepreneurial universities and training education programs (Ciappei et al., 2016; Laudano et al., 2019), our findings stress the key role of educational investments in EP, not only on rational entrepreneurial thinking styles (Rialti et al., 2017) but also on nonlinear thinking styles. These results are of relevance to universities and educators who can emphasize the need for "potential entrepreneurs" - such as students of entrepreneurial universities - to learn how to foster their passion, intuition and emotion in order to "handle uncertain and unpredictable situations, reflecting the actual modern economic scenario, thus involving students in real entrepreneurial decision-making processes" (Zollo et al., 2017b, p. 281). Consistent with Franke and Lüthje (2004), a set of practical entrepreneurial courses, training and real applications should be set in university programs, with the intention of stressing - through entrepreneurs' real cases and examples how passion and nonrational cognitive mechanisms assume a role of key importance in modern markets, which are increasingly characterized by unpredictable, dynamic and fastchanging circumstances (see also Lüthje and Franke, 2003; Pellegrini et al., 2016). Given the importance of fostering the formation of entrepreneurial mind-sets, orientations and behavior when it comes to a country's economic growth, social innovation and general development (Etzkowitz, 2003; Laudano et al., 2019), policymakers need to know what the strategic levers that most effectively impact upon these elements are. Our study sought to highlight the importance of passion and nonlinear thinking styles as new and promising cognitive and attitudinal mechanisms enabling such an entrepreneurial path.

\section{Limitations and future research}

In spite of our findings, this research is limited in some ways. Firstly, our results may be context-dependent as we focused on a sample composed of European entrepreneurs only. Thus, it may be prudent to replicate this research in a different country or to run a cross-country analysis (Barnard et al., 2019). As stressed in existing literature, Eastern and Western people make their decisions according to different cultural values; therefore, it would be interesting to observe whether or not a different subject might yield different results. Secondly, we employed a survey-based methodology. Our responses are therefore self-reported perceptions from entrepreneurs. Accordingly, we suggest that future researchers try to adopt qualitative methodologies in order to obtain a more in-depth understanding of what may stimulate the 
interplay between the two styles (i.e. external factors). It may also be useful to extend the proposed model by including a performance variable. Such an addition could provide direct insights regarding successful businesses. Another useful avenue for future researchers might be to replicate similar research by considering gender differentiation as a factor that may play a role. Gender-related differences in decision-making behavior have indeed been observed in the past (e.g. Henrich et al., 2001; Buchan and Croson, 2004; Caputo et al., 2016); however, the question of whether or not gender variation affects decision-making behavior is still a relatively new research field - one to which this study aims to contribute. Researchers are increasingly interested in whether or not the decision-making style typically associated with women broadly defined as more nurturing and less authoritarian - should become a more popular style as the workplace shifts to a more team-oriented atmosphere that seems to thrive on a less direct approach (Laudano et al., 2019). Business organizations should consider the possibility that a gender-based bias may not only hinder them personally but also have a detrimental effect on the organization. According to prevailing scholarly literature (Carli and Eagley, 2001; Eagly et al., 2003), while men and women are equally effective in some settings, more often than not their effectiveness depends on the fit between the setting and the gender of management. The decision-making style attributed to women is favorably received in female-dominated professions and the "command and control" style typical of men is well-received in maledominated professions. Thus, when all things are equal, men and women are equally effective. However, given the variation in work settings and workplaces, whose top managers are still more likely to be male, all things are rarely equal. Women are slightly more likely to be "transformational" leaders, serving as role models. This approach may actually be more effective in the current less hierarchical organizations, but not all workplaces are alike. The participatory style may backfire in traditional male-dominated settings, such as the military or organized sports. Conversely, the "command and control style" more typical of men may backfire in a social-service agency or retail outlet (Watson et al., 1993; Walters et al., 1998). Thus, the exploration of this phenomenon from this point of view may extend academic literature and provide implications for policies seeking to reduce the gender gap in entrepreneurship.

\section{Notes}

1. This study occurred before Brexit, thus including the United Kingdom in the EU.

2. As illustrated in Figure 2, the variables in the moderation analysis were labeled as follows: entrepreneurial passion $=X_{1}$; entrepreneurial orientation $=Y_{1}$ and $X_{2}$; strategic entrepreneurship behavior $=Y_{2}$; linear thinking style $=M_{1}$; non-linear thinking style $=M_{2}$.

3. GEM 2015/2016 Global Report: https://www.gemconsortium.org/report/gem-2015-2016-globalreport.

\section{References}

Abatecola, G., Caputo, A. and Cristofaro, M. (2018), "Reviewing cognitive distortions in managerial decision making: toward an integrative co-evolutionary framework", Journal of Management Development, Vol. 37 No. 5, pp. 409-424.

Adomako, S., Howard Quartey, S. and Narteh, B. (2016), "Entrepreneurial orientation, passion for work, perceived environmental dynamism and firm performance in an emerging economy", Journal of Small Business and Enterprise Development, Vol. 23 No. 3, pp. 728-752.

Anderson, B.S., Kreiser, P.M., Kuratko, D.F., Hornsby, J.S. and Eshima, Y. (2015), "Reconceptualizing entrepreneurial orientation”, Strategic Management Journal, Vol. 36 No. 10, pp. 1579-1596.

Anderson, B.S., Eshima, Y. and Hornsby, J.S. (2019), "Strategic entrepreneurial behaviors: construct and scale development”, Strategic Entrepreneurship Journal, Vol. 13 No. 2, pp. 199-220.
Linear and nonlinear thinking styles 
Audretsch, D. (2012), "Entrepreneurship research”, Management Decision, Vol. 50 No. 5, pp. 755-764.

Bagozzi, R.P. and Yi, Y. (1988), "On the evaluation of structural equation models", Journal of the Academy of Marketing Science, Vol. 16 No. 1, pp. 74-94.

Bao, J., Zhou, X. and Chen, Y. (2017), "Entrepreneurial passion and behaviors: opportunity recognition as a mediator", Social Behavior and Personality: An International Journal, Vol. 45 No. 7, pp. 1211-1220.

Bandura, A. (2012), "Going global with social cognitive theory: from prospect to paydirt", in Applied Psychology, Psychology Press, New York, NY, pp. 65-92.

Baptista, R. and Thurik, A.R. (2007), "The relationship between entrepreneurship and unemployment: is Portugal an outlier?", Technological Forecasting and Social Change, Vol. 74 No. 1, pp. 75-89.

Barnard, A., Pittz, T. and Vanevenhoven, J. (2019), "Entrepreneurship education in US community colleges: a review and analysis", Journal of Small Business and Enterprise Development, Vol. 26 No. 2, pp. 190-208.

Biraglia, A. and Kadile, V. (2017), "The role of entrepreneurial passion and creativity in developing entrepreneurial intentions: insights from American homebrewers", Journal of Small Business Management, Vol. 55 No. 1, pp. 170-188.

Breugst, N., Domurath, A., Patzelt, H. and Klaukien, A. (2012), "Perceptions of entrepreneurial passion and employees' commitment to entrepreneurial ventures", Entrepreneurship: Theory and Practice, Vol. 36 No. 1, pp. 171-192.

Buchan, N. and Croson, R. (2004), "The boundaries of trust: own and others' actions in the US and China", Journal of Economic Behavior \& Organization, Vol. 55 No. 4, pp. 485-504.

Burke, L.A. and Miller, M.K. (1999), "Taking the mystery out of intuitive decision making”, Academy of Management Perspectives, Vol. 13 No. 4, pp. 91-99.

Carli, L.L. and Eagly, A.H. (2001), "Gender, hierarchy, and leadership: an introduction", Journal of Social Issues, Vol. 57 No. 4, pp. 629-636.

Ciappei, C., Laudano, M.C., Zollo, L. and Rialti, R. (2016), "Evaluating the quality of entrepreneurial education analysing its ability to increase entrepreneurial attitude and intent of students", in Toulon-Verona Conference Excellence in Services, September.

Caputo, A., Mehtap, S., Pellegrini, M.M. and Al-Refai, R. (2016), "Supporting opportunities for female entrepreneurs in Jordan", International Journal of Entrepreneurship and Small Business, Vol. 27 Nos 2/3, pp. 384-409.

Caputo, A., Marzi, G., Pellegrini, M.M. and Rialti, R. (2018), "Conflict management in family businesses: a bibliometric analysis and systematic literature review", International Journal of Conflict Management, Vol. 29 No. 4, pp. 519-542.

Cardon, M.S. and Kirk, C.P. (2015), "Entrepreneurial passion as mediator of the self-efficacy to persistence relationship", Entrepreneurship: Theory and Practice, Vol. 39 No. 5, pp. 1027-1050.

Cardon, M.S., Wincent, J., Singh, J. and Drnovsek, M. (2009), "The nature and experience of entrepreneurial passion”, Academy of Management Review, Vol. 34 No. 3, pp. 511-532.

Cardon, M.S., Gregoire, D.A., Stevens, C.E. and Patel, P.C. (2013), "Measuring entrepreneurial passion: conceptual foundations and scale validation", Journal of Business Venturing, Vol. 28 No. 3, pp. 373-396.

Cardon, M.S., Glauser, M. and Murnieks, C.Y. (2017), "Passion for what? Expanding the domains of entrepreneurial passion”, Journal of Business Venturing Insights, Vol. 8, pp. 24-32.

Covin, J.G. and Slevin, D.P. (1988), "The influence of organization structure on the utility of an entrepreneurial top management style”, Journal of Management Studies, Vol. 25 No. 3, pp. 217-234.

Dabić, M., Maley, J., Dana, L.P., Novak, I., Pellegrini, M.M. and Caputo, A. (2019), "Pathways of SME internationalization: a bibliometric and systematic review", Small Business Economics, doi: 10. 1007/s11187-019-00181-6. 
Dane, E. and Pratt, M.G. (2007), "Exploring intuition and its role in managerial decision making", Academy of Management Review, Vol. 32 No. 1, pp. 33-54.

Davidsson, P., Delmar, F. and Wiklund, J. (2006), "Entrepreneurship as growth; growth as entrepreneurship", Entrepreneurship and the Growth of Firms, Vol. 1, pp. 21-38.

Davis, B.C., Hmieleski, K.M., Webb, J.W. and Coombs, J.E. (2017), "Funders' positive affective reactions to entrepreneurs' crowdfunding pitches: the influence of perceived product creativity and entrepreneurial passion”, Journal of Business Venturing, Vol. 32 No. 1, pp. 90-106.

Dedeke, A. (2015), “A cognitive-intuitionist model of moral judgment”, Journal of Business Ethics, Vol. 126 No. 3, pp. 437-457.

Eagly, A.H., Johannesen-Schmidt, M.C. and Van Engen, M.L. (2003), "Transformational, transactional, and laissez-faire leadership styles: a meta-analysis comparing women and men”, Psychological Bulletin, Vol. 129 No. 4, pp. 569-578.

Etzkowitz, H. (2003), "Research groups as 'quasi-firms': the invention of the entrepreneurial university”, Research Policy, Vol. 32 No. 1, pp. 109-121.

Evans, J.S.B. (2008), "Dual-processing accounts of reasoning, judgment, and social cognition”, Annual Review of Psychology, Vol. 59, pp. 255-278.

Faraoni, M., Rialti, R., Zollo, L. and Pellicelli, A.C. (2019), "Exploring e-loyalty antecedents in B2C e-commerce", British Food Journal, doi: 10.1108/BFJ-04-2018-0216.

Fayolle, A. (2007), Entrepreneurship and New Value Creation: The Dynamic of the Entrepreneurial Process, Cambridge University Press, Cambridge.

Ferreira, F.A., Marques, C.S., Bento, P., Ferreira, J.J. and Jalali, M.S. (2015), "Operationalizing and measuring individual entrepreneurial orientation using cognitive mapping and MCDA techniques", Journal of Business Research, Vol. 68 No. 12, pp. 2691-2702.

Field, A. (2013), Discovering Statistics Using IBM SPSS Statistics, Sage, Thousand Oaks, CA.

Fornell, C. and Larcker, D.F. (1981), "Evaluating structural equation models with unobservable variables and measurement error", Journal of Marketing Research, Vol. 18 No. 1, pp. 39-50.

Franke, N. and Lüthje, C. (2004), "Entrepreneurial intentions of business students-a benchmarking study", International Journal of Innovation and Technology Management, Vol. 1 No. 3, pp. 269-288.

Futterer, F., Schmidt, J. and Heidenreich, S. (2018), "Effectuation or causation as the key to corporate venture success? Investigating effects of entrepreneurial behaviors on business model innovation and venture performance", Long Range Planning, Vol. 51 No. 1, pp. 64-81.

Gartner, W.B. (1990), "What are we talking about when we talk about entrepreneurship?", Journal of Business Venturing, Vol. 5 No. 1, pp. 15-28.

Gartner, W.B., Starr, J. and Bhat, S. (1999), "Predicting new venture survival: an analysis of "anatomy of a start-up" cases from Inc. Magazine”, Journal of Business Venturing, Vol. 14 No. 2, pp. 215-232.

Gerschewski, S., Lindsay, V.J. and Rose, E. (2016), "Advancing the entrepreneurial orientation construct: the role of passion and perseverance", Review of International Business and Strategy, Vol. 26 No. 4, pp. 446-471.

Greenwood, R. and Suddaby, R. (2006), "Institutional entrepreneurship in mature fields: the big five accounting firms", Academy of Management Journal, Vol. 49 No. 1, pp. 27-48.

Groves, K., Vance, C. and Paik, Y. (2008), "Linking linear/nonlinear thinking style balance and managerial ethical decision-making", Journal of Business Ethics, Vol. 80 No. 2, pp. 305-325.

Groves, K., Vance, C. and Choi, D. (2011), "Examining entrepreneurial cognition: an occupational analysis of balanced linear and nonlinear thinking and entrepreneurship success", Journal of Small Business Management, Vol. 49 No. 3, pp. 438-466.

Haidt, J. (2001), "The emotional dog and its rational tail: a social intuitionist approach to moral judgment”, Psychological Review, Vol. 108 No. 4, pp. 814-834. 
Hayes, A.F. (2017), Introduction to Mediation, Moderation, and Conditional Process Analysis: A Regression-Based Approach, Guilford Publications, New York.

Henrich, J., Boyd, R., Bowles, S., Camerer, C., Fehr, E., Gintis, H. and McElreath, R. (2001), "In search of homo economicus: behavioral experiments in 15 small-scale societies", The American Economic Review, Vol. 91 No. 2, pp. 73-78.

Ireland, R.D. and Webb, J.W. (2009), "Crossing the great divide of strategic entrepreneurship: transitioning between exploration and exploitation", Business Horizons, Vol. 52 No. 5, pp. 469-479.

Jamali, D., Samara, G., Zollo, L. and Ciappei, C. (2019), "Is internal CSR really less impactful in individualist and masculine cultures? A multilevel approach", Management Decision.

Kahneman, D. (2003), "A perspective on judgment and choice: mapping bounded rationality", American Psychologist, Vol. 58 No. 9, pp. 697-720.

Kantur, D. (2016), "Strategic entrepreneurship: mediating the entrepreneurial orientation-performance link", Management Decision, Vol. 54 No. 1, pp. 24-43.

Knight, F.H. (1971), Risk, Uncertainty and Profit, 1921, Library of Economics and Liberty.

Kollmann, T., Christofor, J. and Kuckertz, A. (2007), "Explaining individual entrepreneurial orientation: conceptualization of a cross-cultural research framework", International Journal of Entrepreneurship and Small Business, Vol. 4 No. 3, pp. 325-340.

Laskovaia, A., Marino, L., Shirokova, G. and Wales, W. (2019), "Expect the unexpected: examining the shaping role of entrepreneurial orientation on causal and effectual decision-making logic during economic crisis", Entrepreneurship \& Regional Development, Vol. 31 Nos 5-6, pp. $456-475$.

Laudano, M.C., Zollo, L., Ciappei, C. and Zampi, V. (2019), "Entrepreneurial universities and women entrepreneurship: a cross-cultural study", Management Decision, Vol. 57 No. 9, pp. 2541-2554.

Lumpkin, G.T. and Dess, G.G. (1996), "Clarifying the entrepreneurial orientation construct and linking it to performance", Academy of Management Review, Vol. 21 No. 1, pp. 135-172.

Lüthje, C. and Franke, N. (2003), "The 'making' of an entrepreneur: testing a model of entrepreneurial intent among engineering students at MIT", R\&D Management, Vol. 33 No. 2, pp. 135-147.

Milanesi, M. (2018), "Exploring passion in hobby-related entrepreneurship. Evidence from Italian cases", Journal of Business Research, Vol. 92, pp. 423-430.

Montiel Campos, H. (2017), "Impact of entrepreneurial passion on entrepreneurial orientation with the mediating role of entrepreneurial alertness for technology-based firms in Mexico", Journal of Small Business and Enterprise Development, Vol. 24 No. 2, pp. 353-374.

Newman, A., Obschonka, M., Moeller, J. and Chandan, G.G. (2019), "Entrepreneurial passion: a review, synthesis, and agenda for future research", Applied Psychology, doi: 10.1111/apps.12236.

Nosi, C., Zollo, L., Rialti, R. and Ciappei, C. (2020), "Sustainable consumption in organic food buying behavior: the case of quinoa", British Food Journal, doi: 10.1108/BFJ-09-2019-0745.

Orlandi, L.B. and Pierce, P. (2019), "Analysis or intuition? Reframing the decision-making styles debate in technological settings", Management Decision, doi: 10.1108/MD-10-2017-1030.

Pellegrini, M.M. and Ciappei, C. (2015), "Ethical judgment and radical business changes: the role of entrepreneurial perspicacity", Journal of Business Ethics, Vol. 128 No. 4, pp. 769-788.

Pellegrini, M.M., Ciappei, C., Zollo, L. and Boccardi, A. (2016), "Finding the extraordinary and creating the unexpected", Journal of Management Development, Vol. 35 No. 6, pp. 789-801.

Pellegrini, M.M., Rialti, R., Marzi, G. and Caputo, A. (2020), "Sport entrepreneurship: a synthesis of existing literature and future perspectives", International Entrepreneurship and Management Journal, doi: 10.1007/s11365-020-00650-5.

Podsakoff, P.M., MacKenzie, S.B., Lee, J.Y. and Podsakoff, N.P. (2003), "Common method biases in behavioral research: a critical review of the literature and recommended remedies", Journal of Applied Psychology, Vol. 88 No. 5, p. 879. 
Ramadani, V., Hisrich, R.D. and Gërguri-Rashiti, S. (2015), "Female entrepreneurs in transition economies: insights from Albania, Macedonia and Kosovo", World Review of Entrepreneurship Management and Sustainable Development, Vol. 11 No. 4, pp. 391-413.

Rialti, R., Marzi, G., Caputo, A. and Mayah, K.A. (2020), "Achieving strategic flexibility in the era of big data: the importance of knowledge management and ambidexterity", Management Decision, doi: 10.1108/MD-09-2019-1237.

Rialti, R., Pellegrini, M.M., Caputo, A. and Dabić, M. (2017), "Entrepreneurial education and internationalisation of firms in transition economies: a conceptual framework from the case of Croatia", World Review of Entrepreneurship, Management and Sustainable Development, Vol. 13 Nos 2-3, pp. 290-313.

Rialti, R., Zollo, L., Ferraris, A. and Alon, I. (2019), "Big data analytics capabilities and performance: evidence from a moderated multi-mediation model", Technological Forecasting and Social Change, Vol. 149, doi: 10.1016/j.techfore.2019.119781.

Sadler-Smith, E. and Shefy, E. (2004), "The intuitive executive: understanding and applying 'gut feel' in decision-making", Academy of Management Perspectives, Vol. 18 No. 4, pp. 76-91.

Schwartz, M.S. (2016), "Ethical decision-making theory: an integrated approach", Journal of Business Ethics, Vol. 139 No. 4, pp. 755-776.

Sonenshein, S. (2007), "The role of construction, intuition, and justification in responding to ethical issues at work: the sensemaking-intuition model”, Academy of Management Review, Vol. 32 No. 4, pp. 1022-1040.

Stanovich, K.E. and West, R.F. (2000), "Advancing the rationality debate", Behavioral and Brain Sciences, Vol. 23 No. 5, pp. 701-717.

Vance, C.M., Groves, K.S., Paik, Y. and Kindler, H. (2007). "Understanding and measuring linearnonlinear thinking style for enhanced management education and professional practice", Academy of Management Learning \& Education, Vol. 6 No. 2, pp. 167-185.

Vance, C., Zell, D. and Groves, K. (2008), "Considering individual linear/nonlinear thinking style and innovative corporate culture", International Journal of Organizational Analysis, Vol. 16 No. 4, pp. 232-248.

Vignoles, V.L., Regalia, C., Manzi, C., Golledge, J. and Scabini, E. (2006), "Beyond self-esteem: influence of multiple motives on identity construction", Journal of Personality and Social Psychology, Vol. 90 No. 2, pp. 308-340.

Walters, A.E., Stuhlmacher, A.F. and Meyer, L.L. (1998), "Gender and negotiator competitiveness: a meta-analysis", Organizational Behavior and Human Decision Processes, Vol. 76 No. 1, pp. 1-29.

Wang, C.L. (2008), "Entrepreneurial orientation, learning orientation, and firm performance", Entrepreneurship: Theory and Practice, Vol. 32 No. 4, pp. 635-657.

Watson, W.E., Kumar, K. and Michaelsen, L.K. (1993), "Cultural diversity's impact on interaction process and performance: comparing homogeneous and diverse task groups", Academy of Management Journal, Vol. 36 No. 3, pp. 590-602.

Woiceshyn, J. (2011), "A model for ethical decision making in business: reasoning, intuition, and rational moral principles", Journal of Business Ethics, Vol. 104 No. 3, pp. 311-323.

Wright, M. and Stigliani, I. (2013), "Entrepreneurship and growth", International Small Business Journal, Vol. 31 No. 1, pp. 3-22.

Zhong, C.B. (2011), "The ethical dangers of deliberative decision making”, Administrative Science Quarterly, Vol. 56 No. 1, pp. 1-25.

Zollo, L. (2020), "The consumers' emotional dog learns to persuade its rational tail: toward a social intuitionist framework of ethical consumption", Journal of Business Ethics, doi: 10.1007/s10551019-04420-4.

Zollo, L., Rialti, R., Ciappei, C. and Pellegrini, M.M. (2016), "Factors stimulating social innovation in entrepreneurship: an empirical evidence of inter-organizational alliances in Italy", International Journal of Business and Management, Vol. 11 No. 5, pp. 12-21.
Linear and nonlinear thinking styles 
$\mathrm{MD}$

59,5

992
Zollo, L., Laudano, M.C., Ciappei, C. and Zampi, V. (2017a), "Factors affecting universities' ability to foster students' entrepreneurial behaviour: an empirical investigation", The Journal of Management Development, Vol. 36 No. 2, pp. 268-285.

Zollo, L., Pellegrini, M.M. and Ciappei, C. (2017b), "What sparks ethical decision making? The interplay between moral intuition and moral reasoning: lessons from the scholastic doctrine", Journal of Business Ethics, Vol. 145 No. 4, pp. 681-700.

Zollo, L., Faldetta, G., Pellegrini, M.M. and Ciappei, C. (2017c), "Reciprocity and gift-giving logic in NPOs", Journal of Managerial Psychology, Vol. 32 No. 7, pp. 513-526.

Zollo, L., Yoon, S., Rialti, R. and Ciappei, C. (2018), "Ethical consumption and consumers' decision making: the role of moral intuition", Management Decision, Vol. 56 No. 3, pp. 692-710.

Zollo, L., Laudano, M.C., Boccardi, A. and Ciappei, C. (2019), "From governance to organizational effectiveness: the role of organizational identity and volunteers' commitment", Journal of Management \& Governance, Vol. 23 No. 1, pp. 111-137.

\section{Further reading}

Alvarez, S.A. and Barney, J.B. (2004), "Organizing rent generation and appropriation: toward a theory of the entrepreneurial firm”, Journal of Business Venturing, Vol. 19 No. 5, pp. 621-635.

Lechler, T. (2001), "Social interaction: a determinant of entrepreneurial team venture success", Small Business Economics, Vol. 16 No. 4, pp. 263-278.

Mehtap, S., Pellegrini, M.M., Caputo, A. and Welsh, D.H. (2017), "Entrepreneurial intentions of young women in the Arab world: socio-cultural and educational barriers", International Journal of Entrepreneurial Behavior \& Research, Vol. 23 No. 6, pp. 880-902.

Shane, S. and Venkataraman, S. (2000), "The promise of entrepreneurship as a field of research", Academy of Management Review, Vol. 25 No. 1, pp. 217-226. 
Appendix

Linear thinking (LT)

(Vance et al., 2008)

Nonlinear thinking (NLT)

(Vance et al., 2008)

Entrepreneurial orientation (EO)

1. EOi: innovativeness

2. EOp: proactiveness

3. EOr: risk-taking

(Covin and Slevin, 1988; Laskovaia et al. 2019;

Lumpkin and Dess, 1996)
LT1) I primarily rely on logic when making career decisions LT2) I primarily weigh quantitative factors when making a decision about a large purchase or investment, such as my age, budget needs or future earnings

LT3) When making important decisions, I pay close attention to when a number of people with well-justified expertise give me the same advice

LT4) The most important factor in making life-altering changes is knowing that the change is based on objective, verifiable facts

LT5) When my analysis and intuition are in conflict, I give precedence to my analytical reasoning

NLT1) I primarily rely on my feelings when making career decisions

NLT2) I primarily weigh qualitative factors when making a decision about a large purchase or investment, such as my gut feelings or a sense that the decision is right for me

NLT3) When making important decisions, I pay close attention when I experience a "knowing in my bones," chills, tingling or other physical sensations

NLT4) The most important factor in making life-altering changes (such as a career change, marriage or major relocation) is feeling it is right for me

NLT5) When my analysis and intuition are in conflict, I give precedence to my intuitive insights

EOi1) In general, the top managers of my firm favor a strong emphasis on R\&D, technological leadership and innovations EOi2) My firm has marketed very many new lines of products or services in the past five years

EOi3) Changes in product or service lines have usually been quite dramatic

EOp1) In dealing with its competitors, my firm typically initiates actions, which competitors then respond to EOp2) In dealing with its competitors, my firm is very often the first business to introduce new products/services, administrative techniques, operating technologies, etc. EOp3) In general, the top management of my firm has a strong tendency to be ahead of other competitors in introducing novel ideas or products

EOr1) In general, the top managers of my firm have a strong proclivity for high-risk projects (with chances of very high returns)

EOr2) In general, the top managers of my firm believe that owning to the nature of the environment, bold, wide-ranging acts are necessary to achieve the firm's objectives EOr3) When confronted with decision-making situations involving uncertainty, my firm typically adopts a bold, aggressive posture in order to maximize the probability of exploiting potential opportunities
Linear and nonlinear thinking styles 
$\mathrm{MD}$

59,5

\section{4}

Strategic entrepreneurship behavior (SEB)

(Kantur, 2016)

Entrepreneurial passion (EP)

(Cardon et al., 2013)

Table A1.

SEB1) Introduced new product/service lines

SEB2) Changed the rules of competition

SEB3) Adopted new strategies to exploit new opportunities

SEB4) Reorganized to foster innovation

SEB5) Adopted flexible organizational structures to foster innovation

SEB6) Moved the competition to a new platform

SEB7) Spending on new product development

SEB8) Introduced team work to foster innovation

SEB9) Introduced new product/service lines in new industries

EP1) It is exciting to figure out new ways to solve unmet market needs that can be commercialized

EP2) Searching for new ideas for products/services to offer is enjoyable to me

EP3) I am motivated to figure out how to make existing products/services better

EP4) Scanning the environment for new opportunities really excites me

EP5) Inventing new solutions to problems is an important part of who I am

EP6) Establishing a new company excites me

EP7) Owning my own company energizes me

EP8) Nurturing a new business through its emerging success is enjoyable

EP9) Being the founder of a business is an important part of who I am

EP10) I really like finding the right people to market my product/service to

EP11) Assembling the right people to work for my business is exciting

EP12) Pushing my employees and myself to make our company better motivates me

EP13) Nurturing and growing companies is an important part of who I am

\section{Corresponding author}

Lamberto Zollo can be contacted at: lamberto.zollo@unifi.it

For instructions on how to order reprints of this article, please visit our website:

www.emeraldgrouppublishing.com/licensing/reprints.htm

Or contact us for further details: permissions@emeraldinsight.com 